\title{
Состояние политического образования в современной России: проблемы и пути их решения
}

\author{
И.Н. Гукова, Ж.В. Бойко, Л.С. Половнева \\ Белгородский государственный национальный исследовательский университет, \\ Россия, 308015, г. Белгород, ул. Победы, 85 \\ E-mail: Gukova_I@bsu.edu.ru, Boiko@bsu.edu.ru,Lpolovneva@bsu.edu.ru
}

\begin{abstract}
Аннотация. Рассмотрены состояние политического образования в современной России, его задачи и виды. Обозначены сложившиеся научные взгляды в понимании политического образования, приведены исследования ученых, дискутирующих на актуальные темы политического образования. Аргументирована позиция, раскрывающая значимость рассмотрения в школьном курсе «Обществознание» и вузовском курсе «Политология» проблемных аспектов в сфере политики и ее влияния на общественное развитие. Обосновано, что данные курсы должны находить адекватное отражение в учебном процессе образовательных учреждений. Предпринята попытка выявить и проанализировать проблемы, возникшие в российском политическом образовании в средних и высших образовательных учреждениях. Намечены пути решения выявленных проблем в целях повышения эффективности и качества политического образования на современном этапе развития. Приведен опыт авторов в поиске новых форм и методов преподавания политологии в высших учебных заведениях.
\end{abstract}

Ключевые слова: образовательная система, политическое образование, политология, обществознание, политологические знания, политолог, политическая культура, политическая социализация, концепции политического образования.

Для цитирования: Гукова И.Н., Бойко Ж.В., Половнева Л.С.. 2021. Состояние политического образования в современной России: проблемы и пути их решения. Via in tempore. История. Политология, 48 (1): 238-248. DOI: 10.52575/2687-0967-2021-48-1-238-248.

\section{State of political education in modern Russia: problems and ways of their solution}

\author{
I.N. Gukova, Z.V. Boyko, L.S. Polovneva \\ Belgorod National Research University, \\ 85 Pobeda St., Belgorod, 308015, Russia \\ E-mail: Gukova_I@bsu.edu.ru, Boiko@bsu.edu.ru, Lpolovneva@bsu.edu.ru
}

\begin{abstract}
The state of political education in modern Russia, its objectives and types are considered. The prevailing scientific views in the understanding of political education are identified; the research of scientists discussing current issues of political education is presented. The author argues the position revealing the importance of considering problematic aspects in the field of politics and its impact on social development in the school course «Social Studies» and the university course «Political Science». It is proved that these courses should be adequately reflected in the educational process of educational institutions. An attempt has been made to identify and analyze the problems that have arisen in Russian political education in secondary and higher educational institutions. The ways of solving the identified problems in order to improve the efficiency and quality of political education at the present stage of development are outlined. The author's experience in the search for new forms and methods of teaching political science in higher education is presented.
\end{abstract}

Keywords: educational system, political education, political science, social science, political science knowledge, political scientist, political culture, political socialization, concepts of political education. 
For citation: Gukova I.N., Boyko Z.V., Polovneva L.S. 2021. State of political education in modern Russia: problems and ways of their solution. Via in tempore. History and political science, 48 (1): 238-248 (in Russian). DOI: 10.52575/2687-0967-2021-48-1-238-248.

Сегодня актуальной темой исследований становится политическое образование, состояние которого в современной России отражает новый этап развития, претерпевает определенные трудности. Задачей исследования стала попытка проанализировать состояние политического образования в России, выявить возникающие в процессе его становления проблемы, поскольку стремительные изменения во всех сферах требуют своевременного к ним внимания, научного подхода для эффективных решений. Значение политической сферы жизни общества стремительно возрастает, и возникает потребность в понимании происходящих процессов, протекающих в быстро меняющемся, глобализирующемся мире. Все чаще звучит информация о событиях, напрямую отражающих проблемы политической жизни, либо так или иначе связанных со сферой политики. Встает правомерный вопрос о том, как разобраться в этом потоке информации, не обладая базовыми знаниями о политике, в том числе о политических ценностях, составляющих основу политической культуры современного гражданина, являющегося непосредственным участником политических процессов и процедур.

В научном сообществе как зарубежные, так и отечественные ученые активно высказываются о важности политического образования, а также никем не оспаривается необходимость поиска инновационных методов обучения, способных помочь не только адаптироваться в новых условиях, но и получить качественные знания.

Актуальные темы, связанные с проблемами политического образования, на сегодняшний день поднимаются многими отечественными учеными. Для нашего исследования значимыми явились работы Я.А. Пляйса, раскрывающие вопросы становления отечественной политологии, которая на данный момент, как отмечает автор, «...вступила в новый период устойчивого развития» [Пляйс, 2007]. И.А.Чихарев, О.В. Столетов указывают на специфику развития системы политического образования в России, его перспективы, отмечают, что исторически сегодня обозначился переход к профессионализации национального политологического сообщества [Чихарев, Столетов, $2017,2019]$. Анализ политического образования с позиции ценностного аспекта проводит Е.В. Брызгалина [Брызгалина, 2019]. Н.Н. Денисенкова подчеркивает важность политического образования в вузе, в процессе которого формируется гражданская активность будущих специалистов [Денисенкова, 2009]. О.В. Столетов рассматривает состояние и перспективы стандартизации политических профессий [Столетов, 2019], что, на наш взгляд, является одной из важных проблем, поскольку, обучая профессионаловполитологов, мы пока не имеем разработанных профессиональных стандартов. Д.В. Рогов акцентирует внимание на состоянии и проблемах школьного политического образования в современной России [Рогов, 2011]. Теоретический анализ научных работ свидетельствует о единстве взглядов современных ученых, выражающих значимость, необходимость политического образования для дальнейшего развития общества, которое в связи с усилением информационного поля приобретает все новые формы участия в политической жизни, что требует высокой политической культуры. Современному государству, расширяющему границы международного сотрудничества в различных сферах своего проявления, необходимы профессионалы, способные направить свою деятельность согласно гуманистическим принципам, которые заложены в законах, нормативноправовых актах, на эффективное решение встающих на сегодняшний день перед обществом многочисленных проблем. Современные реалии диктуют необходимость знаний о политических процессах, процедурах, чтобы ориентироваться в сложном сплетении информационного потока. 
Проблемы политического образования обсуждаются и в профессиональных сообществах. Ю.В. Ирхин указывает на важную роль отечественных политологов и обществоведов в деятельности Международной ассоциации политической науки [Ирхин, 2016]. На III съезде Российского общества политологов также подчеркивалась мысль о необходимости фундаментальных знаний для специалистов, непосредственно занимающихся политикой, которые изучают политическую сферу и анализируют события. Этот аспект рассматривается в работе В.А. Иноземцевой [Иноземцева, 2018]. Состоянию и проблемам политического образования в современной России был посвящен и ряд «круглых столов», которые проходили на площадках как профессиональных ассоциаций, так и вузов России. Среди наиболее значимых можно выделить следующие:

- «Круглый стол» на тему «Роль профессионального сообщества в оценке качества образования в области обществознания и политологии» в рамках VI Всероссийского конгресса политологов в МГИМО. Он был проведен совместно с Российской ассоциацией политической науки (РАПН) и Евразийской ассоциацией оценки качества образования (ЕАОКО).

- «Круглый стол» «Петербургской политологической экспертизы», который состоялся на факультете философии и политологии Санкт-Петербургского государственного университета [Нужна ли современной России..., 2006]. «Круглый стол» в Московском государственном университете им. М.В. Ломоносова на тему «Политическое образование в современной России и в мире».

В современном научном мире как за рубежом, так и в России широко представлены модели политического образования. М. Оукшотт подразделяет политическое образование на универсальное и профессиональное [Oakshott M., 1962, p. 116]. Автор отмечает, что «система универсального (свободного) образования формируется в школах, а система профессионального образования - в университетах. В данных системах реализуются три основных аспекта политического образования: формулирование, закрепление и передача общих основ политического мировоззрения, освоение всей совокупности политических дисциплин и подготовка к участию в выборах и к профессиональной политической деятельности» [Oakshott М., 1962, p. 116].

Профессиональное образование осуществляется на уровне высшего образования и включает подготовку профессиональных политологов, т. е. исследователей, преподавателей, политических экспертов, политических консультантов, технологов политической сферы. Профессиональное политическое образование (часто используется также термин «политологическое образование») в России - явление сравнительно новое, насчитывает чуть более 30 лет. Как известно, в советский период в России долгое время политология как наука официально не признавалась. Несмотря на это, процесс накопления политических знаний в стране шел интенсивным путем, постепенно приобретался и опыт преподавания знаний о политике. Начиная с 70-х годов XX века в высших учебных заведениях читаются небольшие спецкурсы по политологическим проблемам, ведутся лекции. В Москве в 1979 году при поддержке Советской ассоциации политических наук (САПН) состоялся XII Всемирный конгресс Международной ассоциации политических наук. Считается, что постановление Государственного комитета СССР по науке и технике (ГКНТ СССР) от 4 ноября 1988 г. № 386 «О номенклатуре специальностей научных работников», в которое были включены политологические специальности, стало фактом официального появления отечественной политологии. Эта дата может считаться официальным днем рождения современной российской политической науки [Пляйс, 2007]. Как отмечает Я.А. Пляйс, по приказу ВАК при СМ СССР от 25 января 1989 г. № 1 номенклатура, утвержденная Государственным комитетом СССР по науке и технике (ГКНТ), была принята к руководству всеми органами аттестации научных и научно-педагогических кадров. В конце 1989 года Высшая аттестационная комиссия (ВАК) ввела политологию в перечень научных дисциплин. Так, «Постановление ГКНТ и приказ ВАК нормативно закрепили создание инфраструктуры, необходимой для становления и развития современной по- 
литической науки, а также соответствующей системы образования» [Пляйс, 2007]. В 1995 году была создана Российская ассоциация политической науки (РАПН).

Универсальное - это образование не для политологов. В России оно осуществляется на уровне общего образования через школу, на уровне профессионального образования через систему среднего профессионального образования (техникумы, колледжи) и через систему высшего образования (образование для гуманитариев-неполитологов и негуманитариев). В январе 1991 года постановлением Государственного комитета СССР по народному образованию политология была включена в состав базовых дисциплин вузов и читалась на всех специальностях без исключения. Этот период стал началом для молодого поколения в освоении политических реалий, поскольку до этого в СССР знания об обществе были построены на марксистско-ленинской философии с идеологическим и патриотическим воспитанием. Глубокие перемены в жизни российского общества ставили перед учеными и педагогами новые задачи. Начиная с 90 -х годов XX века их внимание сосредотачивается на разработке нового учебного предмета, способствующего повышению политико-правовой грамотности, самоопределению школьников. Так, уже с 2000 года в российских школах постепенно вводятся такие предметы, как «Обществознание», «Правоведение», призванные помочь школьникам овладеть знаниями о политической системе, о государственности, о конституционном строе Российской Федерации, праве, гражданственности, политической культуре и другими. Политическая и правовая необразованность, а следовательно, неактивность, определенная внутренняя несвобода, являлись и являются пока еще чертой общественного большинства. На наш взгляд, преодоление этих «симптомов» - важная задача для успешного развития общества, решение которой будет способствовать улучшению социального здоровья, общественному благополучию. Однако стоит заметить, что общественная активность должна проявляться осознанно, на основе общепризнанных гуманистических принципов, а это под силу образованной личности. На сегодняшний день для государства важно выстроить ценностные приоритеты общественного развития, которые были бы приняты обществом, позволили бы сплотить, солидаризовать его, поскольку ни политическая, ни экономическая стратегия без этого не будет работать. Эта задача вполне разрешима при поддержке профессионалов политической сферы. По мнению исследователя И.В. Богдана, важными условиями для успешного развития общества являются «осознание политическим классом в целом и работающими на него аналитиками сложности формирования системы ценностей и необходимости создания определенных организационных условий для осуществления этой задачи с учетом разных политических ориентаций самих экспертов; выработка некого согласия по поводу базовых ценностей и целей развития страны внутри политического класса, но и налаживание диалога власти и общества о трансляции ценностей «официальной идеологии» всем группам населения. Особенно велика здесь роль системы образования на всех ее ступенях и средств массовой информации» [Богдан, 2014].

Профессиональное политическое образование в современной России нацелено на формирование, прежде всего, профессиональных компетенций. От политолога сегодня требуется качественно новый уровень понимания и обобщения знаний о политике и человеке, что требует глубокого изучения большого пласта гуманитарных наук, однако нельзя забывать, что теоретические знания будущие политологи должны будут применить в своей практической деятельности. Важно понимать, что политическая деятельность является профессиональной сферой. В свою очередь, если говорить о политической науке, то она закономерный результат развития общественных наук. На сегодняшний день качества политика оцениваются не как компетенции, приобретенные в процессе образования, а как личные качества, сумма персонального опыта, репутация. Подобным же образом трактуются навыки политических технологов, специалистов по политическим коммуникациям. Их профиль формирует совокупность прецедентов в профессиональной деятельности проведенные кампании, личные контакты [Кошкин, Жидких, Новиков, 2018]. Несомненно, личные качества - важная характеристика для политолога, однако при условии само- 
развития, политологического образования, позволяющего уже на более высоком теоретическом уровне оценивать и анализировать происходящие события в жизни общества, эти качества становятся преимуществом профессионала, его достоинством.

Многие исследователи отмечают, что важными факторами, влияющими на возникновение проблем в российском политическом образовании, являются: зависимость от зарубежных концептов и моделей, недостаток специалистов в сфере политического образования, непоследовательность и отставание от требований политического и экономического рынка при формировании образовательных стандартов и программ. На сегодняшний день идет процесс поиска новых технологий и методов преподавания политических дисциплин. При этом важно учитывать то, что «для студентов направлений, не связанных с политологией и социологией, необходимы иные технологии образования, чем для студентов-социологов и политологов» [Кошкин, Жидких, Новиков, 2018].

Один из способов в преодолении создавшихся проблем ученые видят в том, чтобы при подготовке бакалавров включать в учебные планы прикладные политологические дисциплины, ориентированные «на практическую деятельность в рамках политического менеджмента» [Кошкин, Жидких, Новиков, 2018]. В качестве таких дисциплин авторы предлагают «Политический рейтинг», «Публичное администрирование», «Бизнесадминистрирование в политике», «Медиапланирование» и другие. Формирование политикоуправленческих компетенций, которые имеют прикладное измерение в сфере PR и GR, будет успешным при реализации таких учебных дисциплин, как маркетинг, бренд-менеджмент, бизнес-аналитика и других. На уровне бакалавриата целесообразно сделать акцент на формировании универсальных, общепрофессиональных и базовых профессиональных компетенций. В высших учебных заведениях следует развивать образовательную среду, которая может быть представлена практическими курсами, ориентированными на применение теоретических подходов в рамках исследовательских проектов, факультативными дисциплинами, открытыми лекториями, интеллектуальными кружками и играми. Всеми признается, что образовательный процесс будет высоко эффективным, если принимать участие в таких мероприятиях смогут не на формальном уровне, а реальном как студенты, так и преподаватели. Заинтересованность в этом должна быть взаимная. Именно с таких позиций университетское образование будет той площадкой, на которой студент сможет получить жизненный и профессиональный опыт, навыки общения в разных ситуациях. Следовательно, университет действительно будет фундаментом для дальнейшего профессионального роста. Магистратура как еще один образовательный этап позволит обеспечить реализацию глубокой специализации в определенном сегменте российской политики. На этом уровне будет логичным продолжить формирование политикоуправленческих компетенций, а также компетенций в сфере экспертизы и консалтинга. Это могут быть компетенции в области управления в сфере электоральных процессов, стратегического управления в сфере отдельных направлений государственной политики России - социальной, экономической и т. д. [Чихарев, Столетов, 2019]. В образовательный процесс будет целесообразным внедрять проектное обучение в форме участия магистрантов в проведении исследований, привлекать их к профессиональной деятельности в органах государственной власти [Чихарев, Столетов, 2019].

Нельзя не учитывать стремительные образовательные процессы, которые происходят в условиях становления новой образовательной парадигмы, в первую очередь, ориентированной на личностно-деятельностный подход, на внедрение новых технических образовательных технологий. На наш взгляд, для решения ряда образовательных проблем в целях достижения качественного профессионального политического образования важно применение практико-ориентированных методов обучения, которые становятся эффективным источником повышения уровня обучения. Такие методы мотивируют обучающихся, дают возможность оценить свои знания, умения в профессиональной сфере. Несомненно, что принцип практической направленности политического образования в совре- 
менных условиях, особенно в последнее время, сопряжен с определенными сложностями. Наряду с тем, что оно требует научно-методологического осмысления, возникают проблемы и другого порядка. Так, например, в период прохождения политологической практики не все потенциальные работодатели готовы на деле предоставить возможность студентам пробовать применить полученные теоретические знания, зачастую их работа ограничивается формальными манипуляциями. Студенческая молодежь сама по себе активна, полна желания пробовать. Однако мотивация несколько ослабевает, когда будущие политологи чувствуют недоверие со стороны работодателя. Мотивационная сторона является значимой в «познавательной самостоятельности» и указывает на степень включенности студента в активную образовательную деятельность. «Познавательная самостоятельность», как отмечает Е.Б. Ястребова, это свойство личности, «...которое проявляется в стремлении и умении своими силами овладеть основами и способами деятельности и применять их в учебной, последовательной и практической деятельности с целью подготовки к деятельности профессиональной» [Ястребова, 1984]. На наш взгляд, на современном этапе стремительного развития общества это качество является значимым в процессе обучения. В свою очередь, поиск, проработка и использование активных методов обучения (дискуссии, деловые игры, презентации, кейс-технологии, встречи с профессионалами и многие другие), составляющих дидактическую базу для организации «познавательной самостоятельности», будут способствовать развитию у студентов-политологов аналитических способностей, логического мышления, инновационной деятельности, а следовательно, и их профессиональному росту. В качестве примера применения одного из активных методов, реализуемых сегодня в образовательном процессе, можно назвать работу студенческого клуба молодых политологов, организованного в 2018 году на базе кафедры международных отношений, зарубежного регионоведения и политологии Института межкультурной коммуникации и международных отношений НИУ «БелГУ». Через активную деятельность студентов, с опорой на такие формы работы, как «...политические дебаты, интеллектуальные игры, дискуссии, тематические круглые столы, встречи с политиками и государственными служащими успешно формируются и развиваются такие важные для будущих политологов качества, как инициативность, социальная ответственность, активная гражданская позиция» [Бойко, Гукова, 2019]. Особенно ярко проходят встречи с профессионалами, раскрывающими разные аспекты работы в политической сфере, которые делятся со студентами своим опытом работы, а также появляется у молодежи личная возможность получить ответы на непосредственно волнующие вопросы. Благодаря таким формам работы обеспечивается ценностная направленность процесса профессиональной подготовки, включение студентов в профессионально-ценностные виды деятельности, что способствует эффективному формированию профессиональных компетенций.

Массовое политическое образование, или образование для публичности, ориентировано на старшеклассников, учащихся колледжей и техникумов, студентов, для которых политология не является основной дисциплиной. Главной задачей такого образования является политическая социализация личности, воспитание гражданственности. В первую очередь задачи, которые встают перед современными педагогами, это быстро реагировать на меняющиеся реалии, находить новые эффективные технологии, способствующие помочь молодежи осознать происходящее, понять свой личный потенциал, свое право и возможность воздействовать на политические процессы, понять свое место в политической системе. Таким образом, массовое образование ориентируется на индивидуальную практику и интересы. На наш взгляд, в процессе изучения политологии у студентов непрофильных специальностей необходимо сформировать высокую политическую культуру, навыки аналитического мышления, способность критически оценивать разнообразные явления политической реальности, умение ориентироваться в многообразии информации, относящейся к политической сфере. Задачи, которые встают перед педагогами, не простые и требуют большой мобилизации профессионального и личного потенциала. Образование - это взаимосвязанный 
процесс между преподавателем и студентом, а следовательно, для его успешности и эффективности условия должны быть для обоих субъектов учебного процесса.

Современные условия общественного развития диктуют необходимость знаний о политике каждому, независимо от его профессиональной принадлежности, так как важно уметь ориентироваться в быстро усложняющемся мире, взаимодействовать, чтобы не стать объектом манипулирования со стороны более активных в политическом отношении сил. В свое время руководитель Академии политического образования Т. Майер писал о том, что «...там, где политическое образование отличается постоянством, непрерывностью и охватывает все социальные слои, оно не всегда обращает на себя большое общественное внимание. Ненужным же оно не будет никогда» [Meyer, 1994]. В дискуссии о том, нужна ли система политического образования в России, профессор Л.В. Сморгунов отмечал, что «...для любого государства, для сообществ, которые формируются, в том числе вне государственной сферы, оно необходимо. Более серьезный вопрос - каким должно быть содержание политического образования в связи с изменением политического режима с теми концептами, которые появляются на политической арене» [Нужна ли России..., 2006]. Действительно, этот вопрос является сегодня актуальным и требует наиболее тщательной проработки.

Можно заключить, что система политического образования в современной Российской Федерации выстроена, функционирует более 30 лет, тем не менее есть проблемы, касающиеся как массового образования, так и профессионального. На сегодняшний день усматриваются некие противоречия в том, что понимание необходимости политического образования не оспаривается, и в тоже время в образовании идут обратные процессы.

Во-первых, обозначился переход на новые образовательные стандарты (ФГОС 3+), особенностью которых является установление отношений между образовательными целями и дисциплинарным полем, еще больше «...расширились права образовательных организаций в определении структуры и содержания программ» [Чучалин, 2015]. Так, вузы, реализующие разные направления подготовки, сегодня имеют право сами решать, включать или нет, например, такую дисциплину, как «Политология», в спектр изучаемых курсов. Такое решение не всегда «за». Также заметно сокращение количества аудиторных часов, отводимых на политологию в вузах и средних специальных учебных заведениях. Специфика политологии как научного знания заключена в комплексном рассмотрении сферы политики. Кроме того, политическая наука характеризуется множеством концепций и парадигм, что требует разъяснения, взаимодействия преподавателя и обучающегося. В современных условиях такое взаимодействие не всегда возможно в полной мере. В 1990-е годы политология стремительно развивалась, читалась практически на всех факультетах классических и технических вузов, вводилась в качестве самостоятельной учебной дисциплины в средних специальных учебных заведениях. В последние же десятилетия наметилась, к сожалению, обратная тенденция. Сокращается количество часов, отводимых на преподавание политологии в высших учебных заведениях, она превратилась из обязательной дисциплины в дисциплину по выбору, постепенно маргинализируется, фактически исчезает из учебных планов колледжей, техникумов. Думается, нельзя не согласиться с мыслью о том, что содержание образовательных программ отражает ценности общества, а следовательно, и его надежды на развитие будущего поколения. Согласно этому, состояние современного политического образования в России как инструмента политической социализации молодежи, призванного формировать ее политическую субъектность, напряженное, сложное и не в полной мере реализует свой потенциал. Возможно, это связано еще и с самой политикой в России, которая, по словам Л.В. Сморгунова, заменена в целом управлением. Он отмечает, что «...мы сами отдаляем себя от политики, говоря, что у нас нет компетенции осуществлять властные полномочия...» [Нужна ли России..., 2006]. В этих условиях, на наш взгляд, важно решить, какими качествами должен обладать человек политики, какими компетенциями должен обладать политик, а какими современный гражданин, тоже принимающий участие в политике. 
Во-вторых, часто политическое воспитание доминирует над политическим образованием. Очевидно, что сегодня на государственном уровне ставка делается на мероприятийный подход. В рамках государственной молодежной политики политическая социализация юношей и девушек в основе своей осуществляется через мероприятия гражданскопатриотической тематики, приуроченные к каким-либо событиям, памятным или историческим датам, выборам и др. Вне всякого сомнения, подобные формы работы с молодежью важны, однако, как показывает практика, при множественности таких мероприятий не всегда получается достичь качества в содержательном плане. Информация о том, как работают политические институты, в чем заключается гражданская активность и социальная ответственность, как может проявляться электоральная активность гражданина, преподносится молодежи в упрощенной форме. В результате такого подхода формируется представление о функционировании политической системы при демократии, о демократических политических ценностях, о политической жизни в целом не совсем полное и четкое. В итоге вместо знаний молодежь получает субъективные политические оценки, а это уже не образование, а политика.

В-третьих, слабая структурированность регионального политологического пространства, отсутствие научно-исследовательских центров и системного финансирования затрудняют развитие политической науки в регионах, что отражается на качестве профессионального образования. Для эффективной реализации профессионального политологического образования необходимо исходить из императива неразрывности исследовательской практики и преподавания.

В целях совершенствования подготовки преподавателей политологических дисциплин необходимо развивать дополнительное образование, в рамках которого преподаватели могли бы получать знания в области современных методов политических исследований. Для повышения уровня профессиональной квалификации преподавателей важно создать условия, мотивирующие их к самообразованию, вовлекать в научноисследовательскую деятельность, развивать систему профессиональных стажировок. Значимая роль в этом вопросе принадлежит профессиональным ассоциациям, прежде всего, Российской ассоциации политической науки как одной из крупнейших общественных организаций в этой сфере, молодежным студенческим политологическим объединениям.

В противном случае политическое образование может стать частью элитарного образования и выполнять задачу по подготовке к участию в политической деятельности представителей элитных групп, что противоречит ключевой задаче демократического государства подготовка «политической личности» - «homo politicus» - человека, творящего политику.

\section{Список литературы}

1. Бойко Ж.В., Гукова И.Н. 2019. Отечественный и зарубежный опыт исследования гражданской идентичности. Социальные и гуманитарные науки на Дальнем Востоке. URL: http://www.eastjournal.ru/journalm.htm (дата обращения: 05.08.2020).

2. Богдан И.В. 2014. Политические ценности современного российского общества: проблемы и перспективы изучения. Политические науки. 2: URL: https://cyberleninka.ru/article/n/politicheskie-tsennosti-sovremennogo-rossiyskogo-obschestva-problemyi-perspektivy-izucheniya/viewer

3. Брызгалина Е.В. 2019. Политическое образование в контексте ценностей: глобальные вызовы, локальные ответы. Политическое образование и политическая практика в современной России: сборник научных трудов и выступлений. М., ФГБОУ ВО РЭУ им. Г.В. Плеханова: 23-26.

4. Денисенкова Н.Н. 2009. Образовательная политика России в современных условиях. Хозяйственные системы в современном мире. Организационно-правленческие институциональные аспекты. Под ред. Т.М. Степанян. М., Макс Пресс: 298-304.

5. Иноземцева В.А. 2018. III съезд Российского общества политологов «Политическое образование в современной России и в мире». Studia Humanitatis Borealis. 1: 31-37. URL: http://petrsu.ru (дата обращения: 01.08.2020). 
6. Ирхин Ю.В. 2016. Роль Московского конгресса в генезисе международной ассоциации политической науки: экспертный анализ. Факты истории политической науки. URL: https://cyberleninka.ru/article/n/rol-moskovskogo-kongressa-v-genezise-mezhdunarodnoy-assotsiatsiipoliticheskoy-nauki-ekspertnyy-analiz/viewer.

7. Королева Л.В. 2015. Некоторые современные проблемы политического образования студентов российских вузов. Социально-философские и социально-экономические особенности развития образования в столичном мегаполисе. Сборник научных статей. Сост. Г.М. Гогиберидзе. М., МГПУ: 71-76.

8. Кошкин А.П., Жидких В.А., Новиков А.В. 2018. Политическое образование в экономическом вузе: проблемы и перспективы. Вестник Российского экономического университета имени Г.В. Плеханова. 4 (100): 28-38. URL: https://cyberleninka.ru/article/n/politicheskoe-obrazovanie-v-ekonomicheskom-vuze-problemy-iperspektivy/viewer.

9. Ланцова И.В., Корнилова Г.И. 2013. О статусе политического образования в национальном исследовательском университете. Вестник ИрГТУ. 7(78): 285-289. URL: https://cyberleninka.ru/article/n/o-statuse-politicheskogo-obrazovaniya-v-natsionalnom-issledovatelskomuniversitete/viewer.

10. Нужна ли современной России система политического образования? 2006. «Круглые столы» семинара «Петербургская политологическая экспертиза». URL: https://cyberleninka.ru/article/n/nuzhna-li-sovremennoy-rossii-sistema-politicheskogo-

obrazovaniya/viewer (дата обращения: 05.08.2020).

11. Пляйс Я.A. 2007. В начале нового этапа развития политической науки в России. URL: https://cyberleninka.ru/article/n/v-nachale-novogo-etapa-razvitiya-politicheskoy-nauki-v-rossii/viewer (дата обращения: 05.08.2020).

12. Пляйс Я.А. 2007. О состоянии и особенностях современного этапа развития политической науки в России. Вестник Российского ун-та. Сер. 12. Политические науки. 5: С. 5. URL: https://cyberleninka.ru/article/n/o-sostoyanii-i-osobennostyah-sovremennogo-etapa-razvitiyapoliticheskoy-nauki-v-rossii/viewer (дата обращения: 05.08.2020).

13. Рогов Д.В. 2011. Современное политическое образование: состояние и методика совершенствования. Социальная политика и социология. 10: 217-227.

14. Столетов О.В. 2019. Стандартизация политических профессий: состояние и перспективы. Политическое образование и политическая практика в современной России: сборник научных трудов и выступлений. М., ФГБОУ ВО РЭУ им. Г.В. Плеханова: С. 33-35.

15. Титова Л.Г. 2018. Образование в контексте политики. Социально-политические исследования. 1: 6-19.

16. Чихарев И.А., Столетов О.В. 2017. Политические профессии и образовательные стандарты: российский опыт. Вестник Московского университета. Сер. 12. Политические науки. 1. URL: https://cyberleninka.ru/article/n/politicheskie-professii-i-obrazovatelnye-standarty-rossiyskiyopyt/viewer.

17. Чихарев И.А., Столетов О.В. 2019. Перспективы развития системы политического образования в России. Политическое образование и политическая практика в современной России: сборник научных трудов и выступлений. М., ФГБОУ ВО РЭУ им. Г.В. Плеханова: 35-41.

18. Чучалин А.И. 2015. Образовательные стандарты ведущих российских вузов. Высшее образование в России. 4: 16. URL: https://cyberleninka.ru/article/n/obrazovatelnye-standarty-veduschihrossiyskih-vuzov/viewer (дата обращения: 05.04.2020).

19. Ястребова Е.Б. 1984. Развитие познавательной самостоятельности студентов младших курсов: Автореф. дис... канд. пед. наук. М.: 16.

20. Almond G.A., Powell G.B. 1966. Comparative Politics. A Developmental Approach. Boston, Little Brown: 64-65.

21. Does modern Russia need a system of political education? 2006. Round Tables of the St. Petersburg Political Expertise Seminar URL: https://cyberleninka.ru/article/n/nuzhna-li-sovremennoyrossii-sistema-politicheskogo-obrazovaniya/viewer (date accessed: 05.08.2020).

22. Meyer T. 1994. Wie entbehrlich ist Politische Bildung? Friedrich-Ebert-Stiftung-Info. -1.

23. Oakshott M. 1962. Rationalism in Politics. L., Methuen: 116. 


\section{References}

1. Bojko Zh.V., Gukova I.N. 2019. Otechestvennyj i zarubezhnyj opyt issledovaniya grazhdanskoj identichnosti [National and foreign experience in the study of civic identity] Social'nye i gumanitarnye nauki na Dal'nem Vostoke. URL: http://www.eastjournal.ru/journalm.htm (data obrashcheniya: 05.08.2020).

2. Bogdan I.V. 2014. Politicheskie cennosti sovremennogo rossijskogo obshchestva: problemy i perspektivy izucheniya [Political Values of Contemporary Russian Society: Problems and Prospects of Study]. Politicheskie nauki. 2: URL: https://cyberleninka.ru/article/n/politicheskie-tsennostisovremennogo-rossiyskogo-obschestva-problemy-i-perspektivy-izucheniya/viewer.

3. Bryzgalina E.V. 2019. Politicheskoe obrazovanie v kontekste cennostej: global'nye vyzovy, lokal'nye otvety [Political Education in the Context of Values: Global Challenges, Local Responses]. Politicheskoe obrazovanie i politicheskaya praktika v sovremennoj Rossii: sbornik nauchnyh trudov i vystuplenij. M., FGBOU VO REU im. G.V. Plekhanova: 23-26.

4. Denisenkova N.N. 2009. Obrazovatel'naya politika Rossii v sovremennyh usloviyah. Hozyajstvennye sistemy $\mathrm{v}$ sovremennom mire [Educational policy of Russia in modern conditions. Economic systems in the modern world]. Organizacionno-pravlencheskie institucional'nye aspekty: Pod red. T.M. Stepanyan. M., Maks Press: 298-304.

5. Inozemceva V.A. 2018. III s"ezd Rossijskogo obshchestva politologov «Politicheskoe obrazovanie v sovremennoj Rossii i v mire» [III Congress of the Russian Society of Political Scientists "Political Education in Modern Russia and in the World]. Studia Humanitatis Borealis. 1: 31-37. URL: http://petrsu.ru (data obrashcheniya: 01.08.2020).

6. Irhin Yu.V. 2016. Rol' Moskovskogo kongressa v genezise mezhdunarodnoj associacii politicheskoj nauki: ekspertnyj analiz [The Role of the Moscow Congress in the Genesis of the International Political Science Association: An Expert Analysis]. Fakty istorii politicheskoj nauki. URL: https://cyberleninka.ru/article/n/rol-moskovskogo-kongressa-v-genezise-mezhdunarodnoy-assotsiatsiipoliticheskoy-nauki-ekspertnyy-analiz/viewer.

7. Koroleva L.V. 2015. Nekotorye sovremennye problemy politicheskogo obrazovaniya studentov rossijskih vuzov [Some Current Problems of Political Education of Students of Russian Universities]. Social'no-filosofskie i social'no-ekonomicheskie osobennosti razvitiya obrazovaniya $\mathrm{v}$ stolichnom megapolise. Sbornik nauchnyh statej. Sost. G.M. Gogiberidze. M., MGPU: 71-76.

8. Koshkin A.P., Zhidkih V.A., Novikov A.V. 2018. Politicheskoe obrazovanie v ekonomicheskom VUZe: problemy i perspektivy [Political Education in Economic Universities: Problems and Prospects] Vestnik Rossijskogo ekonomicheskogo universiteta imeni G.V. Plekhanova. 4 (100): 28-38. URL: https://cyberleninka.ru/article/n/politicheskoe-obrazovanie-v-ekonomicheskomvuze-problemy-i-perspektivy/viewer.

9. Lancova I.V., Kornilova G.I. 2013. O statuse politicheskogo obrazovaniya v nacional'nom issledovatel'skom universitete [About the status of political education in a National Research University]. Vestnik IrGTU. 7 (78): 285-289. URL: https://cyberleninka.ru/article/n/o-statuse-politicheskogoobrazovaniya-v-natsionalnom-issledovatelskom-universitete/viewer.

10. Nuzhna li sovremennoj Rossii sistema politicheskogo obrazovaniya? 2006 [Does modern Russia need a system of political education?]. «Kruglye stoly» seminara «Peterburgskaya politologicheskaya ekspertiza». URL: https://cyberleninka.ru/article/n/nuzhna-li-sovremennoy-rossiisistema-politicheskogo-obrazovaniya/viewer (data obrashcheniya: 05.08.2020).

11. Plyajs Ya.A. 2007. V nachale novogo etapa razvitiya politicheskoj nauki v Rossii [At the beginning of a new stage in the development of political science in Russia]. URL: https://cyberleninka.ru/article/n/v-nachale-novogo-etapa-razvitiya-politicheskoy-nauki-v-rossii/viewer (data obrashcheniya: 05.08.2020).

12. Plyajs Ya.A. 2007. O sostoyanii i osobennostyah sovremennogo etapa razvitiya politicheskoj nauki v Rossii [About the state and peculiarities of the modern stage of development of political science in Russia]. Vestnik Rossijskogo un-ta. Ser. 12. Politicheskie nauki. 5. URL: https://cyberleninka.ru/article/n/o-sostoyanii-i-osobennostyah-sovremennogo-etapa-razvitiyapoliticheskoy-nauki-v-rossii/viewer (data obrashcheniya: 05.08.2020).

13. Rogov D.V. 2011. Sovremennoe politicheskoe obrazovanie: sostoyanie i metodika sovershenstvovaniya [Modern Political Education: Status and Methods of Improvement]. Social'naya politika i sociologiya. 10: 217-227. 
14. Stoletov O.V. 2019. Standartizaciya politicheskih professij: sostoyanie i perspektivy [Standardization of the Political Professions: Status and Prospects]. Politicheskoe obrazovanie i politicheskaya praktika v sovremennoj Rossii: sbornik nauchnyh trudov i vystuplenij. M., FGBOU VO REU im. G.V. Plekhanova: S. 33-35.

15. Titova L.G. 2018. Obrazovanie v kontekste politiki [Education in the context of politics]. Social'no-politicheskie issledovaniya. 1: 6-19.

16. Chiharev I.A., Stoletov O.V. 2017. Politicheskie professii i obrazovatel'nye standarty: rossijskij opyt [Political Professions and Educational Standards: The Russian Experience]. Vestnik Moskovskogo universiteta. Ser. 12. Politicheskie nauki. 1. URL: https://cyberleninka.ru/article/n/politicheskie-professii-iobrazovatelnye-standarty-rossiyskiy-opyt/viewer.

17. Chiharev I.A., Stoletov O.V. 2019. Perspektivy razvitiya sistemy politicheskogo obrazovaniya v Rossii [Prospects for the Development of Political Education in Russia]. Politicheskoe obrazovanie i politicheskaya praktika v sovremennoj Rossii: sbornik nauchnyh trudov i vystuplenij. M., FGBOU VO REU im. G.V. Plekhanova: 35-41.

18. Chuchalin A.I. 2015. Obrazovatel'nye standarty vedushchih rossijskih vuzov [Educational standards of Russian leading universities]. Vysshee obrazovanie v Rossii. 4: 16. URL: https://cyberleninka.ru/article/n/obrazovatelnye-standarty-veduschih-rossiyskih-vuzov/viewer (data obrashcheniya: 05.04.2020).

19. Yastrebova E.B. 1984. Razvitie poznavatel'noj samostoyatel'nosti studentov mladshih kursov [Development of cognitive independence of undergraduate students]: Avtoref. dis... kand. ped. nauk. M.: 16.

20. Almond G.A., Powell G.B. 1966. Comparative Politics. A Developmental Approach. Boston, Little Brown: 64-65.

21. Does modern Russia need a system of political education? 2006. Round Tables of the St. Petersburg Political Expertise Seminar URL: https://cyberleninka.ru/article/n/nuzhna-li-sovremennoyrossii-sistema-politicheskogo-obrazovaniya/viewer (date accessed: 05.08.2020).

22. Meyer T. 1994. Wie entbehrlich ist Politische Bildung? Friedrich-Ebert-Stiftung-Info. -1.

23. Oakshott M. 1962. Rationalism in Politics. L., Methuen: 116.

\section{ИНФОРМАЦИЯ ОБ АВТОРАХ}

Гукова Ирина Николаевна, канд. политических наук, доцент кафедры международных отношений, зарубежного регионоведения и политологии, ФГАОУ «Белгородский государственный национальный исследовательский университет», г. Белгород, Россия.

Бойко Жанна Васильевна, канд. пед. наук, доцент кафедры международных отношений, зарубежного регионоведения и политологии, доцент, ФГАОУ «Белгородский государственный национальный исследовательский университет», г. Белгород, Россия.

Половнева Людмила Сергеевна, канд. политических наук, доцент кафедры российской истории и документоведения, ФГАОУ «Белгородский государственный национальный исследовательский университет», г. Белгород, Россия

\section{INFORMATION ABOUT THE AUTHORS}

Gukova Irina Nikolaevna, Ph.D. in Political Science, Associate Professor in the Department of International Relations, Foreign Regional Studies and Political Science, Belgorod State National Research University, Belgorod, Russia.

Boyko Zhanna Vasilyevna, Ph.D. in Pedagogy, Associate Professor of the Department of International Relations, Foreign Regional Studies and Political Science, Associate Professor, Belgorod State National Research University, Belgorod, Russia.

Polovneva Lyudmila Sergeevna, $\mathrm{PhD}$ in Political Science, Associate Professor of the Department of Russian History and Document Science, Belgorod State National Research University, Belgorod, Russia 